\title{
Crop coefficients for rangeland
}

\author{
J.R. WIGHT AND C.L. HANSON
}

\section{Abstract}

Crop coefficients (Kc) provide a means of relating evapotranspiration (ET) to standard references such as pan evaporation or other climatic based reference ET's (ET = Kc*reference ET). They have been used extensively in irrigated agriculture but only limitedly on rangelands. This study used lysimeter-measured ET to determine Kc's for conditions where water was nonlimiting for both transpiration ( $T$ ) and soil water evaporation ( $E$ ) and transpiration coefficients (Tc) for conditions where $E$ was minimal and water was nonlimiting for $T$. Growing season ET was measured daily with hydraulic lysimeters from mixed grass, shortgrass, and sagebrush-grass plant communities near Newell, South Dakota; Gillette, Wyoming; and Reynolds, Idaho, respectively. From seasonal plots of daily ET/reference ET, lysimeter-measured ET, and daily precipitation, time periods were identified, following periods of precipitation, that met the conditions for determining $\mathrm{Kc}$ and $\mathrm{Tc}$ values. The $K c$ values were relatively constant among the 3 study sites and over most of the growing season ranging from 0.75 to 0.90. Maximum Tc varied among years with most of the values occurring within the 0.40 to 0.60 range.

Key Words: climate, grassland, lysimeter

Evapotranspiration (ET) is a major component of the water budget for arid and semiarid rangelands. Branson et al. (1981) estimated that as much as $96 \%$ of the incoming precipitation to these rangelands was returned directly to the atmosphere as ET. Direct measurements of rangeland ET have been limited primarily to lysimeter studies (Wight 1971, Hanson 1976, Parton et al. 1981). Recently, the Bowen ratio method has been used successfully on rangelands to measure ET fluxes (Gay and Fritschen 1979, Nie and Kanemasu 1989). Indirect measurements of ET have been made from soil water and precipitation measurements where ET is the change in soil water content plus precipitation and minus runoff for the sample period. For such measurements, deep drainage is assumed to be negligible.

Rangeland ET can also be estimated by model-calculated ET values. Such calculations are based on potential ET (PET), vegetation characteristics, and soil water content relationships. In SPUR (Simulation of Production and Utilization of Rangelands) (Wight and Skiles 1987), ET calculations are based on the work of Ritchie (1972). A modified Penman equation (Penman 1963) is used to calculate PET and ET is controlled by leaf area, mulch cover, and soil water content (Renard et al. 1987). In ERHYM (Ekalaka Rangeland Hydrology and Yield Model) (Wight and Hanks 1981, Wight and Neff 1983, Wight 1987), ET calculations utilize a Jensen-Haise calculated reference ET (JHET) based on a wellwatered alfalfa crop (Jensen and Haise 1963), a rangeland crop coefficient, an annual relative growth curve, and soil water content.

Crop coefficients $(\mathrm{Kc}$ ) have been used extensively in irrigated agriculture to estimate crop water requirements (Wright 1982) and in irrigation scheduling models like that of Jensen et al. (1971).

\footnotetext{
Authors are range scientist and agricultural engineer, USDA, Agricultural Research Service, Boise, Idaho 83712.

Research is a contribution from the USDA, Agricultural Research Service, Northwest Watershed Research Center, 800 Park Boulevard, Plaza IV. Suite 105 , Boise, Idaho 83712.

Manuscript accepted 8 March 1990.
}

They are usually calculated as the ratios of the ET of specific crops to some reference ET (RFET) under conditions where water is nonlimiting for transpiration (T) and soil water evaporation (E) is not a factor. These Kc's provide a means of calculating water use or water requirements for specific crops based on a RFET that can be determined from weather variables such as temperature and solar radiation or from pan evaporation.

Under rangeland conditions, however, water is often limiting and soil water evaporation cannot be ignored. Thus, Kc's are difficult to determine and lack transferability among range sites.

To overcome transferability problems, Hanks (1985) suggested separating PET into an evaporation component Ep (water not limiting evaporation from the soil surface) and a transpiration component Tp (water not limiting transpiration). This procedure is similar to the one used in the ET component of ERHYM where PET is the product of a $\mathrm{Kc}$ and JHET. The Kc represents conditions where water is nonlimiting for both $\mathrm{T}$ and $\mathrm{E}$. A maximum value for the transpiration coefficient (Tc) $(T c=T / J H E T)$ is calculated for specific plant communities based on live biomass at peak standing crop. Seasonal Tp values are based on the maximum Tc and a relative annual growth curve.

The purpose of this study was to use ET data from rangeland lysimeters to estimate seasonal $\mathrm{Kc}$ (ET/JHET) values for conditions where water was nonlimiting for both $T$ and $E$ and $T c$ (T/JHET) values for conditions where water was nonlimiting for $\mathrm{T}$, and $\mathrm{E}$ was minimal.

\section{Methods and Procedures}

\section{Study Sites}

The lysimeter ET data used in this study were obtained from previous studies (Hanson 1976, Wight et al. 1986). Study sites were located near Gillette, Wyoming; Newell, South Dakota; and Reynolds, Idaho (Table 1). Reynolds is located about $80 \mathrm{~km}$ southwest of Boise on the Agricultural Research Service Experimental Watershed. Paired lysimeters were located at the Gillette and Reynolds sites where like-kind vegetation extended for several miles in each direction. At the Newell site, 1 lysimeter was located in a 50-acre pasture of mixed-prairie vegetation and another lysimeter was installed in a 30-acre pasture of mixed-prairie vegetation that had been fertilized and received regular applications of irrigation water. Lysimeter ET was measured during 1969 and 1971 at the Newell site; 1968-1970 at the Gillette site; and 1977-1984 at the Reynolds site. Precipitation, solar radiation, and air temperature were measured at each study site.

\section{ET Measurements}

ET was measured daily from about 1 May to 30 September with small hydraulic lysimeters. At the Newell and Gillette sites, lysimeter installations included an inner steel box filled with an undisturbed $1 \times 1 \times 1 \mathrm{~m}$ monolith of soil (Hanks and Shawcroft 1965). The boxes were filled by digging them down through the undisturbed soil profile and then sealing the bottom end. The inner box floated on 2 interconnected butyl bags within an outer box. The bags were filled with antifreeze and water, and weight changes of the soil monolith were measured with manometers. Both inner and outer boxes were sealed at the bottom.

At the Reynolds site, undisturbed monoliths of soil $1.52 \mathrm{~m}$ in 


\begin{tabular}{|c|c|c|c|c|}
\hline \multirow[b]{2}{*}{ Characteristic } & \multicolumn{4}{|c|}{ Site } \\
\hline & $\begin{array}{c}\text { Newell } \\
\text { South Dakota }\end{array}$ & $\begin{array}{l}\text { Newell/Irrigated, } \\
\text { South Dakota }\end{array}$ & $\begin{array}{l}\text { Gillette, } \\
\text { Wyoming }\end{array}$ & $\begin{array}{l}\text { Reynolds, } \\
\text { Idaho }\end{array}$ \\
\hline Latitude-longitude & $4444^{\prime} \mathrm{N}, 10327^{\prime} \mathrm{W}$ & $4444^{\prime} \mathrm{N}, 10327^{\prime} \mathrm{W}$ & $4417^{\prime} \mathrm{N}, 10528^{\prime} \mathrm{W}$ & $439^{\prime} \mathrm{N}, 11644^{\prime} \mathrm{W}$ \\
\hline Elevation (m) & 875 & 875 & 1389 & 1649 \\
\hline Ave. growing season & $5 / 16-9 / 24$ & $5 / 16-9 / 24$ & $5 / 19-9 / 20$ & $5 / 19-10 / 4$ \\
\hline Mean annual temp. $\left({ }^{\circ} \mathrm{C}\right)$ & 8.3 & 8.3 & 7.2 & 7.4 \\
\hline Soil texture & clay & clay & fine sandy loam & gravelly loam \\
\hline Vegetation type & mixed prairie & mixed prairie & shortgrass prairie & sagebrush grass \\
\hline Dominant species & Agropyron smithii & Agropyron smithii & Bouteloua gracilis & Artemisia arbuscula \\
\hline Maximum LAI & 1.5 & $>3.0$ & 1.6 & 2.0 \\
\hline Years of study & 1969,1971 & $1969-71$ & $1968-71$ & $1977-84$ \\
\hline
\end{tabular}

diameter and $1.22 \mathrm{~m}$ deep were enclosed in rolled steel pipes that were sealed at the bottom. Installation procedures were similar to those at Gillette and Newell. The inner section of pipe and soil column floated on a coil of butyl tubing $15 \mathrm{~cm}$ in diameter within an outer section of pipe. Daily changes in the weight of the soil column were monitored by a pressure transducer attached to the butyl tubing and recorded on a data acquisition system.

At the Gillette and Newell sites, the lysimeters were sensitive to about $0.3 \mathrm{~mm}$ of ET; at the Reynolds site, the lysimeter sensitivity was about $0.5 \mathrm{~mm}$. This sensitivity is less than the $0.06 \mathrm{~mm}$ reported by Fritschen et al. (1973) for a similar, floating-type lysimeter. However, their lysimeter had a larger surface area to total weight ratio than the lysimeters we used. These floating-type lysimeters are still less sensitive than direct weighing lysimeters like those used by Parton et al. (1981) that can measure as little as 0.025 mm of ET.

A concern when using lysimeters to measure ET from rangelands is how well the lysimeters represent undisturbed plant communities. Previous comparisons of lysimeter-measured ET with ET calculated from changes in soil water content as measured by the neutron method show good agreement between the 2 methods

Table 2. Examples of ET and Kc values for paired lysimeters at the Gillette and Reynolds sites.

\begin{tabular}{|c|c|c|c|c|c|}
\hline \multirow{2}{*}{$\begin{array}{l}\text { Days of } \\
\text { Year }\end{array}$} & \multirow{2}{*}{$\begin{array}{c}\text { PPT } \\
(\mathrm{mm})\end{array}$} & \multicolumn{2}{|c|}{$\mathrm{ET}(\mathrm{mm})$} & \multicolumn{2}{|c|}{$\mathrm{Kc}$} \\
\hline & & Lys 1 & Lsy 2 & Lys 1 & Lys 2 \\
\hline \multicolumn{6}{|c|}{ Gillette, 1970} \\
\hline 163 & 50.8 & 1.0 & 1.0 & .71 & .71 \\
\hline 164 & 0 & 5.5 & 5.1 & .93 & .86 \\
\hline 165 & 0 & 5.5 & 5.1 & .73 & .68 \\
\hline 166 & 0 & 3.0 & 3.1 & .66 & .67 \\
\hline 167 & 0 & 4.0 & 4.0 & .67 & .67 \\
\hline 168 & 0 & 2.5 & 3.0 & .38 & .45 \\
\hline 169 & 0 & 3.5 & 3.3 & .60 & .57 \\
\hline 170 & 0 & 3.5 & 3.5 & .49 & .49 \\
\hline 171 & 0 & 3.1 & 3.1 & .43 & .43 \\
\hline 172 & 0 & 4.1 & 4.6 & .59 & .59 \\
\hline Total & 50.8 & 35.7 & 35.8 & & \\
\hline \multicolumn{6}{|c|}{ Reynolds, 1984} \\
\hline 171 & 24.8 & 0 & 0 & 0 & 0 \\
\hline 172 & 0 & 1.1 & 4.8 & .32 & 1.41 \\
\hline 173 & 0 & 2.6 & 1.2 & .74 & .34 \\
\hline 174 & 0 & 3.7 & 3.0 & .92 & .75 \\
\hline 175 & 0 & 4.2 & 5.5 & .64 & .83 \\
\hline 176 & 0 & 4.2 & 2.4 & .78 & .44 \\
\hline 177 & 0 & 4.8 & 4.8 & .62 & .62 \\
\hline 178 & 0 & 3.2 & 4.8 & .40 & .61 \\
\hline 179 & 0 & 5.8 & 3.6 & .84 & .52 \\
\hline 180 & 0 & 4.8 & 3.6 & .54 & .40 \\
\hline Total & 24.8 & 34.4 & 33.7 & & \\
\hline
\end{tabular}

for a mixed prairie range site (Wight 1971), and a somewhat poorer agreement for a sagebrush-grass range site (Wight et al. 1986). There was generally good agreement in daily ET measured by the paired lysimeters in this study (Table 2).

We determined $\mathrm{Kc}$ and $\mathrm{Tc}$ values for each study site from annual graphs of daily ET/ JHET values (Fig. 1). Such graphs are always

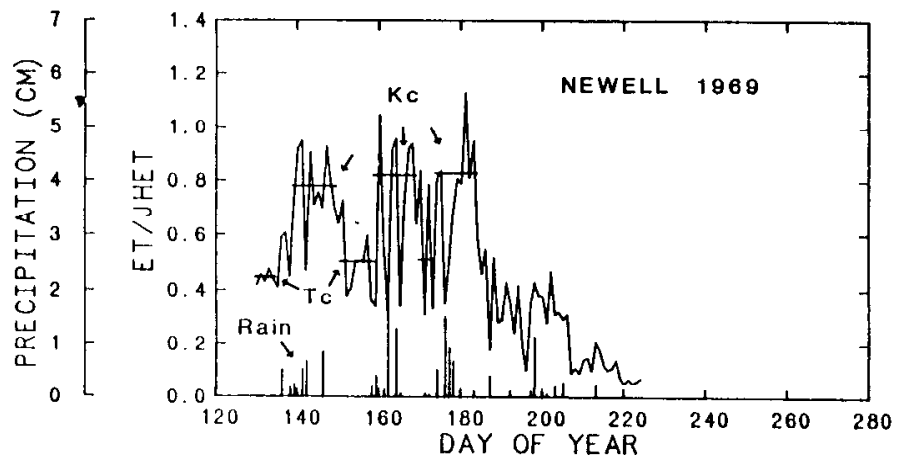

Fig. 1. Example of procedure used to estimate Kc and Tc.

somewhat sawtoothed because reference ET's, especially those calculated from average temperature and solar radiation, do not necessarily represent the environmental conditions on a day-to-day basis. For example, a cool, overcast day with low evaporative demand may have a brief period of sunshine resulting in a high maximum temperature. This would result in a calculated RFEl value that was much higher than actual evaporative demand and thus a low Kc value. Because of difficulty in using JHET to represent evaporative demand on a daily basis, average values from ET/JHET graphs or tabular sources are needed to determine $\mathrm{Kc}$ and Tc values. We visually averaged the ET/JHET curves or curve segments, as is often done in agronomic studies (Wright 1982).

With agronomic crops, especially under irrigation, it is relatively easy to determine time periods when water is nonlimiting for both $\mathrm{T}$ and $\mathrm{E}$. With complete canopy cover, $\mathrm{E}$ is often ignored and $\mathrm{Kc}$ and Tc are the same. For native rangeland the problem is more complex. In this study, the Kc's were determined for days when soil water was nonlimiting for both $\mathrm{T}$ and $\mathrm{E}$. Because soil water data were not available, these days were estimated to occur on the first 1 to 3 days following a precipitation event that was greater than the PET for the days considered (Ritchie and Burnett 1971, Nkemdirim and Haley 1973). These events were identified from graphs of daily ET/JHET values and precipitation (Fig. 1).

We attempted to estimate Tc values from ET/JHET graphs by considering time periods after a significant precipitation event when the soil surface had dried reducing $E$ to minimal amounts, but the subsurface water content was sufficient as to not limit $\mathrm{T}$. 
Admittedly, we had no way of knowing that these conditions were fully met. Even if soil water data had been available, it would still be very difficult to determine exactly when the conditions were present for estimating Tc.

We suggest that with the amount of canopy and ground cover present on these study sites, E would be sharply reduced as the plant and soil surfaces dried. There are many opinions on when soil water becomes limiting for transpiration. Reported available soil water contents at which soil water becomes limiting range from as low as $25 \%$ (Nkemdirim and Haley 1973, Ritchie 1973, Ritchie et al. 1976) to as high as $75 \%$ (DeJong and MacDonald 1975). Such values, however, are directly affected by evaporative demand, root distribution, etc.

Patterns in the ET/JHET graphs are indicative of conditions where $T$ is not limited and accounts for most of ET. Thus we suggest that determining Tc values as described above is, at least, a good first step in obtaining this information.

\section{Vegetation Measurements}

Seasonal leaf area indices (LAI) were measured biweekly on the lysimeters by the inclined point frame technique (Warren-Wilson 1959). Annual herbage yields at peak standing crop were estimated by clipping small plots adjacent to the lysimeter.

\section{Reference ET}

We used JHET (Jensen and Haise 1963) as the reference ET. JHET has had world-wide application, has been used successfully in ERHYM, and can be calculated from available weather data. It does not include a wind factor which is often used for agronomic crops. However, wind data is only limitedly available for rangelands. JHET was calculated as:

$$
\operatorname{JHET}\left(\mathrm{mm} \mathrm{d}^{-1}\right)=\frac{(0.025 \mathrm{~T}+0.08) \mathrm{Rs}}{2.45}
$$

where
$\mathrm{T}=$ mean daily temperature ${ }^{\circ} \mathrm{C}$
$R s=$ solar radiation $\left(\mathrm{MJ} \mathrm{m}^{-2} \mathrm{~d}^{-1}\right)$
$2.45=$ latent heat of vaporization of water $\left(\mathrm{MJ} \mathrm{kg}^{-1}\right)$

The JHET was adjusted for elevation using the method described by Jensen (1974).

\section{Results and Discussion}

\section{Field Estimated $\mathrm{Kc}$ and Tc Values}

The sample data in Table 2 represent 10-day periods following significant precipitation events. These are representative of the ET data used in this study and are indicative of the resolution and dependability of the lysimeters. The lysimeters at the Gillette and Newell sites were monitored daily and, in general, performed with fewer errors than did the lysimeters at Reynolds. Also, there was better agreement between the paired lysimeters at Gillette than at Reynolds.

Representative daily ET/ JHET graphs are shown in Figure 2. In addition to the sawtoothed variations inherent with ET/RFET graphs, there are occasional extremes that are caused by inaccurate ET values. This was most prevalent on the Reynolds site and resulted when the floating inner box of the lysimeter temporarily bound against the outer box or there was a malfunction of the electronics associated with the transducers and recorders. The lysimeters at Gillette and Newell were read daily and apparent malfunctions could be corrected at time of reading. The ET/JHET graph for the irrigated Newell site has some missing days, but otherwise is very similar to that of an irrigated crop.

Except for slight reductions during late summer and fall, the $\mathrm{Kc}$ values remained relatively constant throughout the year. These reductions were associated with a decrease in $T$ that was not offset
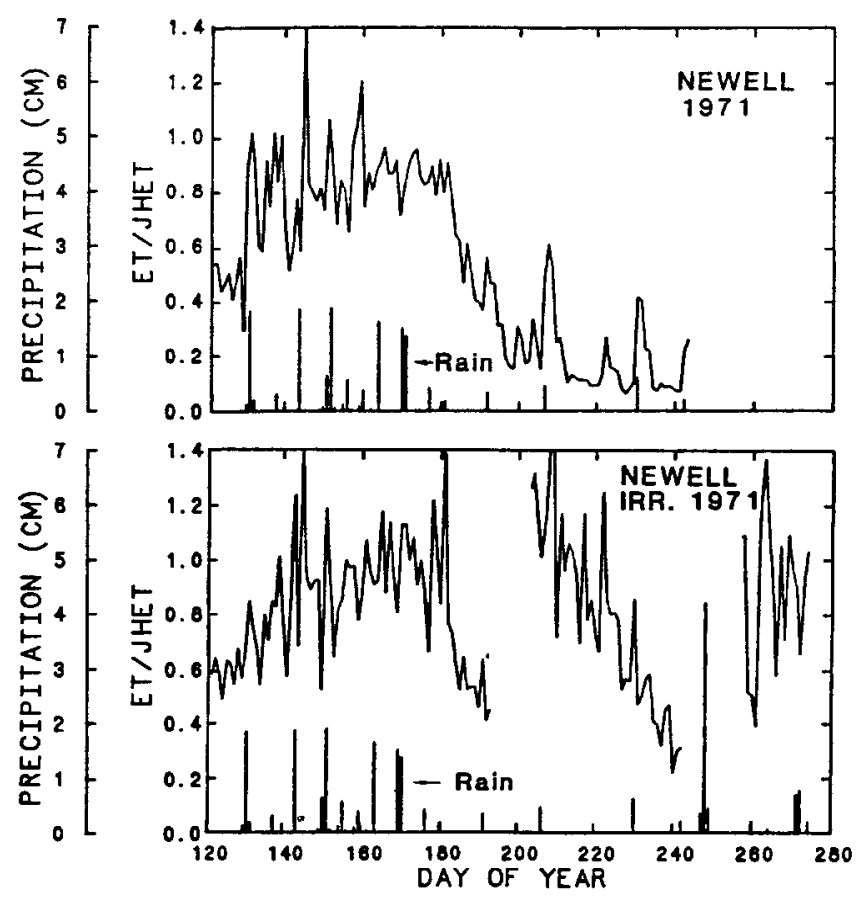

Fig. 2. Representative daily ET/JHET values for the Newell study site.

by increases in $E$ because of shading by mature vegetation and litter.

As indicated by the means and standard deviations in Table 3, most the Kc's for the 3 nonirrigated sites were in the 0.75 to 0.90 range. Average Kc values were $0.82,0.79$, and 0.85 for the Newell, Gillette, and Reynolds sites, respectively. Wight and Hanks (1981) reported similar values for a mixed-prairie range site in eastern Montana. On the Newell irrigated site (Fig. 2), the ET/JHET ratio showed seasonal effects with the highest values coinciding with periods of maximum green biomass at peak standing crop and regrowth in late fall. This site had a dense stand of grass due to fertilization and irrigation. Water was generally not limiting and $E$ was minimal due to dense ground cover. Thus the ET/JHET ratio provides a good estimate of both the $\mathrm{Kc}$ and $\mathrm{Tc}$ values of this site and reflects seasonal trends. Low ET/ JHET values coincided with senescence of vegetation following peak standing crop.

Table 3. Summary of Ke's and Tc's estimated from T/JHET graphs.

\begin{tabular}{|c|c|c|c|c|c|c|c|}
\hline \multirow[b]{2}{*}{ Site } & \multirow[b]{2}{*}{ Years } & \multicolumn{3}{|c|}{$\mathbf{K c}$} & \multicolumn{3}{|c|}{$T c^{2}$} \\
\hline & & Days' & Mean & SD & Days & Mean & SD \\
\hline Newell & 1969,1971 & 46 & 0.82 & 0.04 & 40 & 0.50 & 0.05 \\
\hline Gillette & $1968-1970$ & 86 & 0.79 & 0.04 & 94 & 0.48 & 0.10 \\
\hline Reynolds & $1977-1984$ & 121 & 0.85 & 0.06 & 190 & 0.52 & 0.08 \\
\hline
\end{tabular}

'The number of days for which $\mathrm{Kc}$ or Tc were estimated.

${ }^{2} \mathrm{Tc}$ values are for period of peak standing crop.

The Tc values varied within growing season and among years, being directly related to the current year's herbage productivity. At or near peak standing crop, Tc values were mostly between 0.40 and 0.60 for the 3 nonirrigated sites with average values of 0.50 , 0.48 , and 0.52 for the Newell, Gillette, and Reynolds sites, respectively (Table 3). Because of the small number of sample years, it is not appropriate to make site comparisons from the mean values in Table 3. The ET/JHET curve for the nonirrigated Newell site (Fig. 2) shows Tc values as low as $\mathbf{0 . 1 0}$ in July and August when the vegetation had senesced. 
It was not possible to establish good seasonal patterns of Tc values. ET data were not available for the growth initiation period in the spring, and it was difficult to determine $\mathrm{Tc}$ values for the latter part of the growing season because of infrequent occurrence of soil water conditions necessary to make Tc estimates. This method of determining Tc values is probably most useful for establishing maximum Tc values.

\section{Model Estimated Te Values}

In ERHYM a maximum transpiration coefficient (TRANCO) based on Kc*JHET as the RFET is calculated by the equation:

$$
\text { TRANCO }=0.0213+0.0162 \text { (yield) })^{1 / 2}
$$

where yield is average annual site yield (lb/acre) at peak standing crop. Using this equation and a Kc value of 0.85 , maximum Tc's were calculated (Tc $=0.85$ TRANCO) for the Newell, Gillette, and Reynolds sites (Table 3).

In the SPUR model, Tp is calculated directly from LAI's using the equation:

$$
\mathrm{Tp}=\mathrm{RFET}^{*} \mathrm{LAI} / \mathbf{3 . 0}
$$

where the RFET is calculated from temperature and solar radiation as described by Renard et al. (1987). For values of LAI greater than 3, Tp equals the difference between the RFET and Ep. With water nonlimiting for T, Tc, is equal to Tp/RFET or LAI/3.0. Using the maximum LAl's in Figure 3, associated maximum Tc

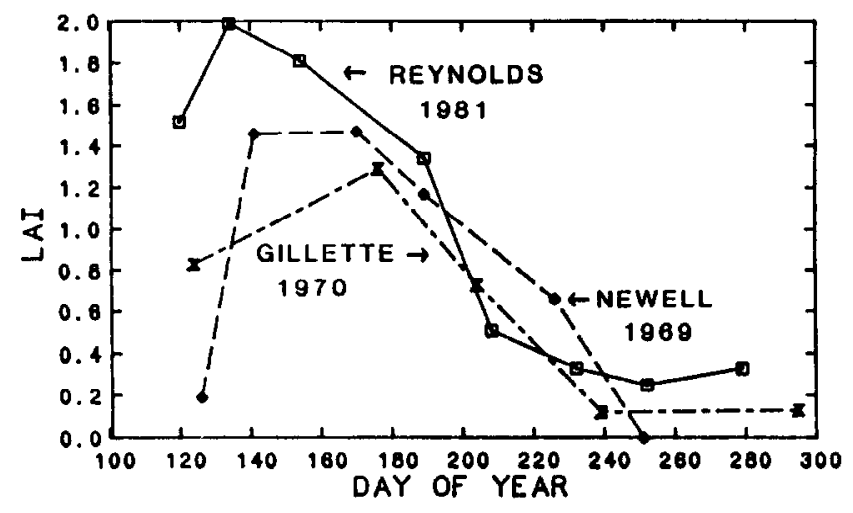

Fig. 3. Example of seasonal LAI for the 3 nonirrigated sites.

values were calculated for the Newell, Gillette, and Reynolds Creek sites, respectively (Table 4).

There is good agreement between SPUR calculated Tc's and those estimated from the ET/JHET graphs. At the Reynolds and Gillette sites, ERHYM calculated Tc is somewhat less than that estimated from the ET/JHET graph. The yield data at these 2 sites included only annual growth of the sagebrush plants and thus under-represented the total biomass capable of transpiration.

\section{Conclusions}

Results of this study indicate that annual graphs of ET/RFET (ET measured by lysimeters) and associated precipitation provide

Table 4. A comparison of maximum Tc's determined from ET/JHET graphs and by the ERHYM and SPUR methods.

\begin{tabular}{lccccccc}
\hline \hline & & & & & Tc \\
\cline { 5 - 7 } & & & $\begin{array}{c}\text { Yield } \\
\text { (lb/acre) }\end{array}$ & & $\begin{array}{c}\text { ET/ } \\
\text { JHET }\end{array}$ & & \\
Site & Year & kg/ha & LAI & graphs & ERHYM & SPUR \\
\hline Newell & 1969 & 1148 & 1.47 & 0.55 & 0.48 & 0.49 \\
Gillette & 1970 & 710 & 1.29 & 0.52 & 0.38 & 0.43 \\
Reynolds & 1981 & 914 & 1.99 & 0.65 & 0.43 & 0.66 \\
\hline
\end{tabular}

a means of estimating $\mathrm{Kc}$ and $\mathrm{Tc}$ values for rangeland plant communities. These are crude estimates because the soil water requirements necessary for the determination of $\mathrm{Kc}$ and $\mathrm{Tc}$ are seldom fully met, especially for $T c$, and it is difficult to determine when these conditions occur.

\section{Literature Cited}

Branson, F.A., G.F. Gifford, K.G. Renard, and R.F. Hadley. 1981. Rangeland hydrology. Range Sci. Ser., No. 1, 2nd ed., Soc. Range Manage., Denver, Colo. Kendall/Hunt Pub. Co., Dubuque, Iowa.

DeJong, E., and K.B. MacDonald. 1975. The moisture regime under native grassland. Geoderma 14:207-221.

Fritschen, L.J., L. Cox, and R. Kinersan. 1973. A 28-meter Douglas-fir tree in a weighing lysimeter. Forest Sci. 19:256-261.

Gay, L.W., and L.J. Fritschen. 1979. An energy budget analysis of water use by saltcedar. Water Resour. Bull. 26:1589-1597.

Hanks, R.J. 1985. Coefficients for transpiration, p. 431-438. In: Proc. Nat. Conf. on Advances in Evapotranspiration, Dec. 16-17, 1985, Chicago, Ill. Amer. Soc. Agr. Eng.

Hanks, R.J., and R.W. Shawcroft. 1965. An economic lysimeter for evapotranspiration studies. Agron. J. 57:634-636.

Hanson, C.L. 1976. Model for predicting evapotranspiration from native rangelands in the Northern Great Plains. Trans. Amer. Soc. Agr. Eng. $19: 471-477,481$.

Jensen, M.E. (ed). 1974. Consumptive use of water and irrigation water requirements. Report prepared by Tech. Comm. on Irrig. Water Requirements of Irrig. and Drain. Div. of Amer. Soc. Civil Engin. Amer. Soc. Civil Eng., New York, N.Y.

Jensen, M.E., and H.R. Haise. 1963. Estimating evapotranspiration from solar radiation. Amer. Soc. Civil Eng., J. of Irrig. and Drain. Div. 89:15-41.

Jensen, M.E., J.L. Wright, and B.J. Pratt. 1971. Estimating soil moisture depletion from climate, crop and soil data. Trans. of Amer. Soc. Agr. Eng. Gen. Ed., 14:954-959.

Nie, D., and E.T. Kanemasu. 1989. Effect of slope on evapotranspiration in a tall grass prairie, p. 187. In: Agronomy Abstracts, Amer. Soc. Agron., Madison, Wis.

Nkemdirim, L.C., and P.F. Haley. 1973. An evaluation of grassland evapotranspiration. Agr. Meteor. 11:373-383.

Parton, W.J., W.K. Lauenroth, and F.M. Smith. 1981. Water loss from a shortgrass steppe. Agr. Meteor. 24:97-109.

Penman, H.L. 1963. Vegetation and hydrology. Tech. Comm. 53, Commonwealth Bar. of Soils, Harpenden, Herts., England.

Renard, K.G., E.D. Shirley, J.R. Williams, and A.D. Nicks. 1987. Hydrology component: Upland phases, p. 17-30. In: J.R. Wight and J.W. Skiles (eds.), SPUR: Simulation of Production and Utilization of Rangelands. Documentation and User Guide. USDA Agr. Res. Serv., ARS 63.

Ritchie, J.T. 1972. A model for predicting evaporation from a row crop with incomplete cover. Water Resour. Res. 8:1204-1213.

Ritchie, J.T. 1973. Influence of soil water status and meteorological conditions on evaporation from a corn canopy. Agron. J. 65:893-897.

Ritchie, J.T., and E. Burnett. 1971. Dryland evaporative flux in subhumid climates: II Plant influences. Agron J. 63:56-62.

Ritchie, J.T., E.D. Rhoades, and C.W. Richardson. 1976. Calculating evapotranspiration from native grassland watersheds. Trans. Amer. Soc. Agr. Engin. 19:1098-1103.

Warren-Wilson, J. 1959. Analysis of the distribution of foliage area in grassland, p. 51-61. In: J.D. Ivins, The measurement of grassland productivity. Butterworths Sci. Publ., London.

Wight, J.R. 1971. Comparison of lysimeter and neutron scatter techniques for measuring evapotranspiration from semiarid rangelands. J. Range Manage. 24:390-393.

Wight, J.R. 1987. ERHYM-II: Model description and user guide for the BASIC version. USDA, Agr. Res. Serv., ARS 59.

Wight, J.R., and R.J. Hanks. 1981. A water-balance, climate model for range herbage production. J. Range Manage. 34:307-311.

Wight, J.R., and E.L. Neff. 1983. Soil-vegetation-hydrology studies, Vol. II. A user manual for ER HYM: The Ekalaka Rangeland Hydrology and Yield Model. USDA, Agr. Res. Serv., Agr. Res. Results, ARR-W-29.

Wight, J.R., and J.W. Skiles (eds.). 1987. SPUR: Simulation of Production and Utilization of Rangelands. Documentation and User Guide. USDA Agr. Res. Serv., ARS 63.

Wight, J.R., C.L. Hanson, and K.R. Cooley. 1986. Modeling evapotranspiration from sagebrush-grass rangelands. J. Range Manage. 31:81-85.

Wright, J.L. 1982. New evapotranspiration crop coefficients. Amer. Soc. Civil Eng., J. of Irrig. and Drain. Div. 108-57-74. 